\title{
MEMAHAMI PENDIDIKAN ISLAM BERDASARKAN TAFSIR AYAT-AYAT ILMU PENGETAHUAN DALAM AL- QUR'AN
}

\author{
Satria Kharimul Qolbi \\ UIN Sunan Kalijaga, Yogyakarta, Indonesia \\ kafacila@gmail.com \\ DOI: 10.20885/tarbawi.vol13.iss2.art2
}

\begin{abstract}
Education is very much related to knowledge and science. Therefore, it is important to understand education on the concept of knowledge. In this context, in order to understand the concept of education in Islam, we need to scrutiny the verses on which al-Qur'an talk about knowledge and science. This method of writing thematically collects the verses of the al-Qur'an that discuss a certain topic and arranges them as much as possible according to the period of their revelation. With deductive reasoning, we draw conclusions from various theories and reviews. Science is the effort from a process carried out by methods and produces a systematic and structured new knowledge that will be used as a basic guideline for humans. There are three laws on learning difference sciences: compulsory, sunnah and haram. One of the most important benefit of learning is increasing the dignity of learners. Application in science can be done early in formal education in accordance with the verses of the Al-Quran.
\end{abstract}

Keywords: Islamic Education, Knowledge, Science, Quranic verses.

\begin{abstract}
Abstrak
Pendidikan sangat berkaitan dengan pengetahuan dan sains. Oleh karena itu, penting untuk memahami pendidikan dari konsep
\end{abstract}




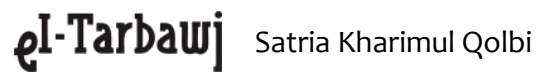

pengetahuan. Dalam konteks itu, dalam rangka memahami konsep Pendidikan dalam Islam, kita harus meneliti ayat-ayat al-Qur'an yang membicarakan tentang pengetahuan dan ilmu. Metode penulisan artikel ini adalah dengan mengumpulkan ayat-ayat al-Qur'an secara tematik dengan topik tertentu dan menyusunnya berdasarkan peride pewahyuan. Dengan pendekatan deduktif, kami menyimpulkan kesimpulan dari pelbagai teori dan reviews. Sains adalah usaha dari sebuah proses yang dilakukan dengan metode dan menghasilkan pengetahuan baru yang sistematis dan terstruktur serta digunakan sebagai arahan bagi manusia. Terdapat tiga hukum mempelajari ragam sains: wajib, sunnah dan haram. Penerapan sains dapat dipraktikkan sedini mungkin pada pendidikan formal selaras dengan ayat-ayat al-Qur'an.

Kata Kunci: Pendidikan Islam, Pengetahuan, Sains, Al-Qur'an.

\section{Pendahuluan}

Ilmu pengetahuan merupakan dasar kelestarian hidup manusia. Peradaban manusia sangat terjaga dengan adanya ilmu pengetahuan. Maka dari itu, perlu adanya wadah agar ilmu pengetahuan dapat dipelajari dan diterima dengan mudah oleh masyarakat, yaitu melalui pendidikan. Pendidikan menjadi proses dalam mendapat ilmu pengetahuan, baik umum maupun agama Islam.

Pada prinsipnya, ilmu pengetahuan tidak akan berkembang dan tersusun secara sistematis tanpa pendidikan. Ilmu pengetahuan dan pendidikan tidak bisa dipisahkan. Sehingga, pendidikan seyogyanya menghasilkan manusia yang memiliki ilmu pengetahuan yang baik, dapat memberikan solusi kontribusi terhadap perkembangan ilmu pengetahuan tak terkecuali bagi umat Islam.

Dalam Islam, ilmu pengetahuan adalah pengetahuan mendalam hasil usaha yang sungguh-sungguh dari para ilmuwan muslim atas persoalan-persoalan duniaw $\bar{\imath}$ dan $u k h r a \bar{w} \bar{\imath}$ dengan berlandaskan 
kepada wahyu Allah (Kosim, 2008). Dengan demikian, pada hakikatnya ilmu pengetahuan Islam tetap berlandaskan ayat-ayat $\mathrm{Al}$ Qur'an sebagai wahyu Allah dan sebagai pedoman bagi umat Islam untuk meningkatkan ketaqwaan, keimanan dan keilmuan. Untuk mewujudkan itu, perlu ada wadah atau tempat agar ilmu pengetahuan Islam tersusun secara sistematis yaitu pendidikan Islam.

Berdasarkan latar belakang itu, penelitian ini berusaha meneliti makna dari ayat-ayat al-Qur'an yang menjelaskan hakikat ilmu pengetahuan. Dari tafsir atas ayat-ayat tersebut, penulis memberikan analisis mengenai pendidikan Islam.

\section{Metode Penelitian}

Penelitian ini dilaksanakan dengan pendekatan kualitatif dan merupakan penelitian pustaka (literature study). Untuk memahami makna ilmu pengetahuan dalam al-Qur'an, penulis menggunakan pendekatan tafsir tematik. Pendekatan tematik ialah mengumpulkan ayat-ayat al- Qur' an yang membahas topik tertentu dan menertibkannya sedapat mungkin sesuai dengan masa turunnya, selaras dengan sebab-sebab turunnya, kemudian memperhatikan ayat-ayat tersebut dengan penjelasan, keterangan hubungannya dengan ayat lain, kemudian mengistinbatkan makna dibalik fakta (Maragustam, 2015).

Dengan Metode tematik ini maka ayat-ayat Al Qur'an yang berkaitan dengan ilmu pengetahuan dapat menjadi dasar hukum dalam perspektif pendidikan Islam. Penulis juga menggunakan penalaran deduksi dalam menganalisis data. Penalaran deduksi adalah sebuah kerangka atau cara berpikir yang bertolak dari sebuah asumsi atau pernyataan yang bersifat umum untuk mencapai sebuah kesimpulan yang bersifat khushus. Deduksi sering disebut dengan logika minor karena mendalami penyesuaian pikiran dengan hukum, aturan dan patokan tertentu (Mundiri, 2000, hal. 14). 


\section{$e^{I-T a r b a w j}$ Satria Kharimul Qolbi}

\section{Hasil Dan Pembahasan}

\section{Pengertian Ilmu Pengetahuan}

Secara kebahasaan, ilmu berasal dari akar kata 'ilm yang diartikan sebagai tanda, penunjuk, atau petunjuk agar sesuatu atau seseorang dikenal. Demikian juga ma'lam, artinya tanda jalan atau sesuatu agar seseorang membimbing dirinya atau sesuatu yang membimbing seseorang. Selain itu, 'alam juga dapat diartikan sebagai penunjuk jalan (Abidin, 2010). Jadi ilmu adalah arah mata angin bagi manusia agar dapat mengetahui suatu hal dalam bidang-bidang tertentu.

Bahasa Arab yang menggunakan semua kata yang tersusun dari huruf-huruf 'ain, lam, mim (علم) dalam berbagai berbagai bentuknya, adalah untuk menggambarkan sesuatu yang sedemikian jelas علامة عehingga tidak menimbulkan keraguan. Jadi, misalnya kata-kata (alamat) yang berarti tanda yang jelas bagi sesuatu atau nama jalan yang mengantar seseorang menuju tujuan yang pasti. Demikian juga halnya dengan ilmu, ia diartikan sebagai sesuatu pengenalan terhadap yang sangat jelas terhadap obyek sesuatu (Shihab, 1998, hal. 113).

Sedangkan secara istilah, sebagaimana yang dikemukan oleh alRaghib al-Ashfahani dalam kitabnya Mufradat Alfazh al-Qur'an, ilmu adalah mengetahui esensi dari sesuatu yang dari segi obyeknya terdiri atas dua, yakni: pertama, mengetahui dzat sesuatu: kedua, menetapkan sesuatu berdasarkan ada atau tidak adanya sesuatu yang lain (Snatalia: 2013). Defenisi ilmu di atas dapat kita lihat dari rujukan ayat al-Qur'an QS Al Anfal (8): 60

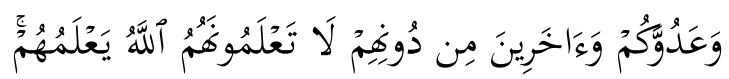

Dalam Tafsir Al Azhar, penjelasan Buya Hamka terhadap potongan ayat tersebut adalah "itulah musuh dalam selimut, kepinding (kutu busuk) di dalam baju, orang-orang munafik, yang 
disangka kawan, padahal lawan. Maka melihat kekuatan persiapanmu dan teguhnya kewibawaanmu, orang-orang yang munafik itupun akan berfikir terlebih dahulu sebelum mereka berbuat khianat" (Hamka, 1965, hal. 2797).

Juga dalam QS Al-Mumtahanah (60): 10:

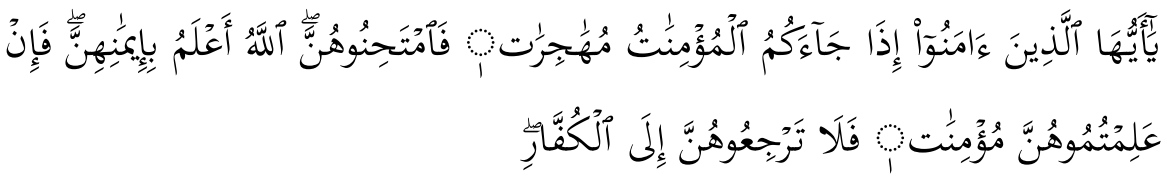

Menurut Tafsir Al Azhar ayat tersebut bermakna bahwa perempuan-perempuan itu pertama sekali adalah orang-orang yang beriman, yang kedua mereka itu adalah ingin hijrah pula, sebagaimana perempuan-perempuan lain yang lebih dulu telah hijrah. Tetapi sebelum diterima dengan resmi dan supaya dapat dipertanggungjawabkan, baik terhadap masyarakat sesama Islam sendiri, atau untuk membela mereka di hadapan kaum musyrikin yang masih saja hendak mengutik-utik kepindahan mereka kelak, hendaklah terlebih dahulu dilakukan ujian. Hendaklah hijrah itu betul-betul dilakukan karena agama, karena iman, karena keyakinan. Bukan hanya karena semata-mata hendak melepaskan diri dari suami yang memeliharanya dengan baik, meskipun sama-sama musyrik (Hamka, Tafsir Al Azhar Jilid 9, 1965, hal. 7307).

Pengertian ilmu dalam ayat yang pertama dikutip di atas, berkaitan langsung dengan zat yang akan diketahui, yaitu musuhmusuh yang tidak atau belum diketahui itu. Jadi, bukan sifat atau ciriciri mereka. Sebab, sifat dan ciri-ciri mereka telah diketahui, yaitu munafik (mereka juga melakukan sembahnyang, puasa, dan mengucapkan kalimah syahadat) (Snatalia, 2013). Sedangkan pengertian ilmu dalam ayat selanjutnya, mengandung pesan agar melakukan pengujian terhadap perempuan-perempuan yang 


\section{$e^{I-T a r b a w j}$ Satria Kharimul Qolbi}

berhijrah dari Mekah meninggalkan suaminya yang musyrik dengan cara mencari tanda-tanda, atau indikasi-indikasi yang ada padanya yang dapat menunjukkan bahwa yang ada padanya yang dapat menujukkan bahwa yang bersangkutan benar-benar perempuan yang beriman. Jadi, ilmu dalam ayat ini tidak berkaitan langsung dengan dzatnya, tetapi berkaitan dengan suatu sifat atau keadaan yang menyertai (melekat) pada zat tersebut (Disadur, 1997, hal. 150).

Dari uraian diatas dapat dimaknai bahwa Ilmu dasarnya dari Allah SWT. Kita sebagai manusia harus berusaha berikhtiar dalam mendapatkannya. Ilmu merupakan sarana yang diberikan Tuhan untuk manusia sebagai bekal kita dalam meningkatkan keimanan kita serta keingintauhan kita.

Sementara itu, pengetahuan merupakan segala sesuatu yang diketahui yang diperoleh dari persentuhan panca indera terhadap objek tertentu. Pengetahuan pada dasarnya merupakan hasil dari proses melihat, mendengar, merasakan, dan berfikir yang menjadi dasar manusia dan bersikap dan bertindak (Makhmudah, 2018).

Maka dapat kita cermati bahwa suatu pengetahuan itu sudah mengalami proses-proses tertentu yang dapat dipertanggungjawabkan. Dalam memahami pengetahuan, kita dapat melihat dalam QS An-Nahl(16): 78:

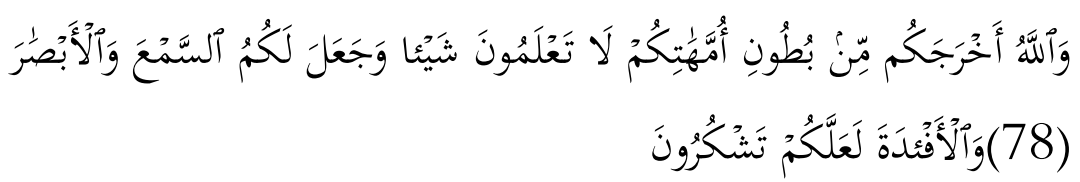

Menurut Tafsir Al Azhar, ayat di atas bermakna "maka dilahirkan Allah ke dunia, lalu diberi pendengaran, sehingga tidak tuli, dan diberi alat penglihatan sehingga tidak buta, diberi pula hati buat mempertimbangkan apa yang didengar dan apa yang dilihat, adalah nikmat paling besar yang dianugerahkan Allah dalam hidup ini. Sebab manusia itu adalah pemikul tugas berat, yaitu menjadi khalifatullah di bumi. Bersyukur itu ialah dengan mempergunakan 
nikmat-nikmat Allah itu di dunia ini dengan sebaik-baiknya, sehingga kita jadi manusia yang berarti. syukur artinya ialah berterimakasih dan lawan dari syukur ialah kufur tidak mengenal budi." (Hamka, Tafsir Al Azhar Jilid 5, 1965, hal. 3942-3943).

Penjelasan tafsir di atas menegaskan bahwa manusia setelah lahir ke dunia ini tidak mengenal apa-apa dan tidak mengetahui apaapa, sampai dengan Allah memberikan penglihatan, pendengaran, hati serta akal pikiran digunakan untuk proses mencari pengetahuan yang sebelumnya tidak tahu apa-apa menjadi tahu sehingga menjadi dasar dalam bersikap dan bertindak.

Jika pengetahuan adalah hasil cerapan indra dan nalar manusia, maka ilmu pengetahuan merupakn kumpulan berbagai pengetahuan yang disusun secara logis dan sistematis dengan memperhitungkan sebab akibat. Di kalangan ilmuwan maupun para filsuf pada umumnya terdapat kesepakatan bahwa ilmu adalah sesuatu kumpulan pengetahuan sistematis. Ilmu pengetahuan merupakan proses dari penemuan lalu dihasilkan kesimpulan atau teori baru dalam suatu hal yang dapat disepakati bersama menjadi suatu pengetahuan. Ilmu pengetahuan sangatlah penting bagi perkembangan hidup manusia. Dengan melihat perjalan sejarah kehidupan manusia yang selalu berkembang itu semua karena adanya ilmu pengetahuan baru.

Karena pengertian ini sedemikian lazim dalam masyarakat, sehingga pengertian ilmu sebagai proses (aktivitas) dan sebagai prosedur (metode) tampak terselubungi dan kurang begitu dikenal. Namun pemahaman yang tepat dan lengkap hanyalah bilamana ilmu pengetahuan dipahami sebagai proses (aktivitas), prosedur (metode), maupun sebagai produk (pengetahuan). Ilmu pengetahuan merupakan proses (aktivitas), yang mempergunakan prosedur (metode) tertentu, dan menghasil produk, yang berupa pengetahuan sistematis (Wahana, 2016, hal. 82). 


\section{$e^{\text {I-Tarbawj Satria Kharimul Qolbi }}$}

Beberapa teori diatas kita dapat cermati bahwa ilmu pengetahuan berawal dari proses dilakukan dengan metode dan menghasilakn suatu pengetahuan baru yang sistematis dan terstruktur yang akan dijadikan dasar pedoman serta produk bagi manusia. Produk-produk teknologi saat ini berkembang merupakan produk dari ilmu pengetahuan, maka dari itu ilmu pengetahuan sangat berpera besar dalam merawat kelestarian umat manusia.

\section{Hukum Ilmu Pengetahuan}

Kata hukum secara etimologi berasal dari akar kata bahasa Arab, yaitu يَحْكُمُ-حَكَمَ hakama-yahkumu yang kemudian bentuk mashdar-nya menjadi حُكْمَ hukman. Lafadz آلْحُكْمَ al-hukmu adalah bentuk tunggal dari bentuk jamak آَّal-ahkâm (Rohidin, 2016, hal. 1).

Berdasarkan akar kata hakama tersebut kemudian muncul

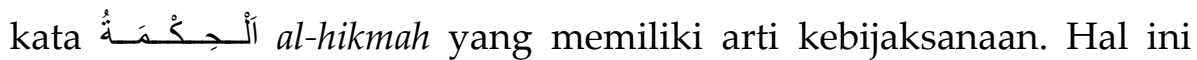
dimaksudkan bahwa orang yang memahami hukum kemudian mengamalkannya dalam kehidupan sehari-hari maka sebagai orang yang bijaksana. Arti lain yang muncul dari akar kata tersebut adalah "kendali atau kekangan kuda", yakni bahwa keberadaan hukum pada hakikatnya adalah untuk mengendalikan atau mengekang seseorang dari hal-hal yang dilarang oleh agama. Makna "mencegah atau menolak" juga menjadi salah satu arti dari lafadz hukmu yang memiliki akar kata hakama tersebut. Mencegah ketidakadilan, mencegah kedzaliman, mencegah penganiayaan, dan menolak mafsadat lainnya (Rohidin, 2016, hal. 2). Al-Fayumi dalam buku Zainudin Ali, Hukum Islam: Pengantar Hukum Islam di Indonesia ia menyebutkan bahwa " حَكَ

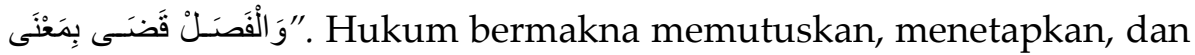
menyelesaikan setiap permasalahan (Ali, 2006, hal. 1).

Uraian diatas sedikit menjelaskan tentang hukum Islam secara umum. Dapat kita maknai bahwa dengan status hukum pada suatu tindakan akan menjadikan tindakan tersebut bernilai keharusannya tergantung statusnya. Dalam hal menuntut ilmu pengetahuan maka 
sumber pertama yang menjadi dasar adalah Al Qur'an dari QS Al Alaq: $1-5$

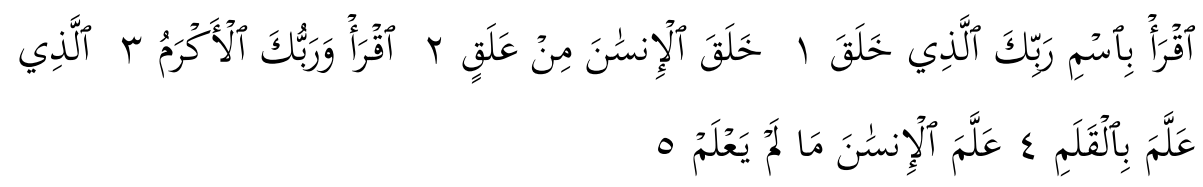

Menurut Ibnu Katsir, tafsir ayat di atas adalah: “Di dalam ayatayat tersebut juga termuat peringatan mengenai permulaan penciptaan manusia dari segumpal darah. Dan bahwasanya di antara kemurahan Allah Ta'ala adalah Dia mengajarkan kepada manusia apa yang tidak diketahuinya. Dengan demikian, Dia telah memuliakannya dengan ilmu. Dan itulah hal yang menjadikan bapak ummat manusia ini, Adam as mempunyai kelebihan atas Malaikat. Terkadang, ilmu berada di dalam akal fikiran dan terkadang juga berada dalam lisan. Juga terkadang berada dalam tulisan. Secara akal, lisan, dan tulisan mengharuskan perolehan ilmu, dan tidak sebaliknya. Oleh karena itu, Allah SWT berfiman: Bacalah dan Rabb-mulah Yang Paling Pemurah; yang mengajar (manusia) dengan perantaraan kalam. Dia mengajarkan kepada manusia apa yang tidak diketahuinya." Di dalam atsar disebutkan: "Ikatlah ilmu itu dengan tulisan." Selain itu, di dalam atsar juga'disebutkan: "Barangsiapa mengamalkan apa yang diketahuinya, maka Allah akan mewariskan kepadanya apa yang tidak d.iketahui sebelumnya." (AlSheikh, 2003, hal. 505).

Bacalah (iqra') dengan menyebut nama Tuhanmu yang menciptakan" demikian terjemaham ayat pertama dari QS. al-Alaq [96]:1 yang turun kepada Rasulullah Saw. Perintah Allah kepada nabi agar membaca diberikan paling awal dibandingkan dengan perintah apa pun. Membaca merupakan aktivitas awal dalam pendidikan. Tanpa membaca maka seakan tidak (mungkin) ada pendidikan. Membaca merupakan kewajiban bagi setiap muslim yang berakal (aqil) dan dewasa (baligh). Membaca juga merupakan jendela untuk melihat 


\section{$e^{\text {I-Tarbawj Satria Kharimul Qolbi }}$}

hazanah ilmu pengetahuan dan jalan lapang untuk memahami dunia (Roqib, 2009, hal. 1).

Secara umum sangat jelas dari tafsir dan uraian di atas menuntut ilmu sangat dianjurkan bagi umat Islam. Bahkan Nabi Muhammad SAW perintah pertamanya adalah membaca yang maksudnya adalah belajar ada proses dalam menuntut Ilmu. Diperkuat dengan hadits Nabi bahwa menuntut ilmu itu hukumnya wajib, seperti yang telah diterangkan dalam hadits, Rasulullah SAW bersabda: "menuntut ilmu wajib atas tiap muslim (baik muslimin maupun muslimah)." (HR. Ibnu Majah) (Eryani, 2017).

Meski demikian, terdapat beberapa pendapat mengenai hukum menuntut ilmu dalam Islam, antara lain (Djamil, 2015, hal. 810):

\section{a. Wajib}

Para Ulama mengklasifikasi ilmu yang wajib menjadi dua bagian yaitu: wajib 'ain dan wajib kifayah.

1) Wajib 'Ain

Ilmu yang diperintahkan dengan perintah wajib 'ain adalah ilmu yang mesti dipelajari setiap muslim yang jika tidak dipelajari hukumnya berdosa. Contohnya adalah ilmu yang membahas tentang Tauhid, ilmu yang membahas tentang eksistensi Ketuhanan, Kenabian, dan alam ghaib, Ilmu Fikih, yang mengupas tentang tata cara beribadah, Ilmu Tasawuf yang menjelaskan cara menjaga amal agar tidak sirna.

2) Wajib Kifayah

Ilmu yang diperintahkan dengan perintah wajib kifayah adalah ilmu-ilmu yang wajib dipelajari oleh setiap muslim. Namun, jika sebagian umat Islam sudah mempelajarinya maka semua umat Islam sudah terlepas dari kewajiban itu. Contohnya adalah mempelajari Ilmu Tafsir, Ilmu Hadits, Ilmu Bahasa Arab, Ilmu Ushul Fiqh, Ilmu Kedokteran, Ilmu Kontraktor, Ilmu Cara Berperang, Ilmu 
Biologi dan Ilmu Pertanian yang semuanya berfungsi untuk masyarakat luas.

\section{b. Sunnah}

Ilmu yang dipelajarinya dengan perintah sunnah adalah ilmuilmu yang dianjurkan untuk dimiliki. Jika ilmu tersebut dipelajari maka akan mendapat pahala dan jika tidak dikaji maka tidak berdosa. Contohnya ilmu untuk mengetahui fadhailul 'amal, ilmu untuk mengetahui ibadah-ibadah sunnah dan ilmu untuk mengetahui halhal yang makruh dalam beragama.

\section{c. Haram}

Ilmu yang haram adalah ilmu yang dilarang tegas untuk dipelajari yaitu ilmu-ilmu yang digunakan untuk merusak dan mengganggu orang lain, seperti ilmu sihir, ilmu mantra, dan ilmuilmu yang bertujuan untuk merusak Agama Islam.

Agama Islam sangat tegas dalam memberikan klasifikasi hukum menuntut Ilmu. Dari wajib, sunnah, dan haram hal tersebut agar kita sebagai umat Islam tidak secara bebas dalam menuntut ilmu. Dengan hukum-hukum tersebut dapat memberikan dorongan bahwa menuntut ilmu sangat bermanfaat bagi kita sebagai umat Islam. Sebagai manusia yang bertaqwa sudah sepatutnya menjalankan perintah-Nya dan menjauhi larangan-Nya. Maka dari itu jangan pernah kita mempelajari ilmu-ilmu yang dilarang Agama Islam sebaliknya kita menguatkan ilmu-ilmu yang dapat meningkatkan ketaqwaan kita.

\section{Keutamaan Ilmu Pengetahuan}

Beberapa keutamaan dalam menuntut ilmu pengetahuan di tinjau dari beberapa ayat Al-Qur' an serta tafsirnya antara lain: 


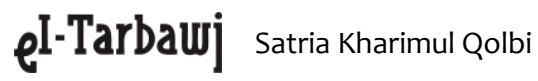

\section{a. Ilmu Adalah Ibadah}

Ilmu adalah ibadah. Bahkan merupakan ibadah yang paling agung dan paling utama, sehingga Allah menjadikanya sebagai bagian dari jihad fisabilillah. Allah berfirman dalam QS At Taubah: 122.

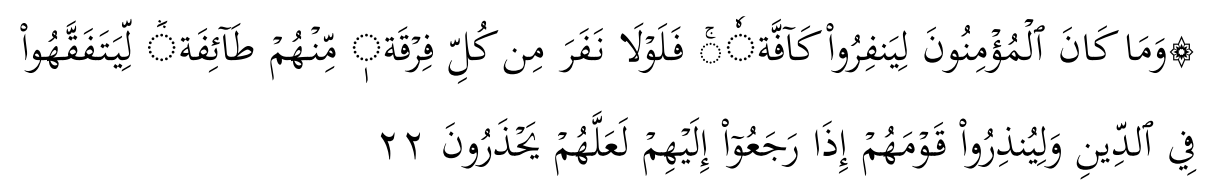

Menurut tafsir Al-Azhar ayat di atas bermakna: “Dengan susun kalimat Falaulaa, yang berarti diangkat naiknya, maka Tuhan telah menganjurkan pembahagian tugas. Seluruh orang yang beriman diwajibkan berjihad dan diwajibkan pergi berperang menurut kesanggupan masing-masing, baik secara ringan ataupun secara berat. Maka dengan ayat ini, Tuhan pun menuntun hendaklah jihad itu dibagi kepada jihad bersenjata dan jihad memperdalam ilmu pengetahuan dan pengertian tentang agama. Jika yang pergi ke medan perang itu bertarung nyawa dengan musuh, maka yang tinggal di garis belakang memperdalam pengertian (Fiqh) tentang agama, sebab tidaklah pula kurang penting jihad yang mereka hadapi. Ilmu agama wajib diperdalam" (Hamka, Tafsir Al Azhar Jilid 4, 1965, hal. 3167).

Yang dimaksud لِِنَفِرُو أ adalah hendaknya ada kelompok orang yang benar-benar melaksanakan tugas belajar. Rasulullah SAW juga bersabda: "Barang siapa yang dikehendaki oleh Allah menjadi baik, maka akan diberikan kepahaman dalam beragama". Apabila Allah menganugerahkan kepadamu kepahaman dalam masalah agama ini yang meliputi segenap ilmu syar'i, baik ilmu tauhid, aqidah atau lainya maka berbahagialah, karena berarti Allah menginginkan kebaikan dalam dirimu (Utsaimin, 2005, hal. 10).

Dengan nilai ibadah tersebut, maka hal ini sangat baik bagi umat Islam untuk lebih giat menuntut ilmu. Bernilai ibadah maka akan mendapatkan ganjaran surga, oleh karena itu manfaat pertama dari 
ilmu pengetahuan adalah dengan statusnya sebagai ibadah yang setara dengan jihad di medan perang.

\section{b. Diangkatnya Derajat Orang yang Berilmu}

Orang yang berilmu memiliki kedudukan yang tinggi di mata Allah SWT. Ditinjau dari QS Al Mujadilah(58): 11

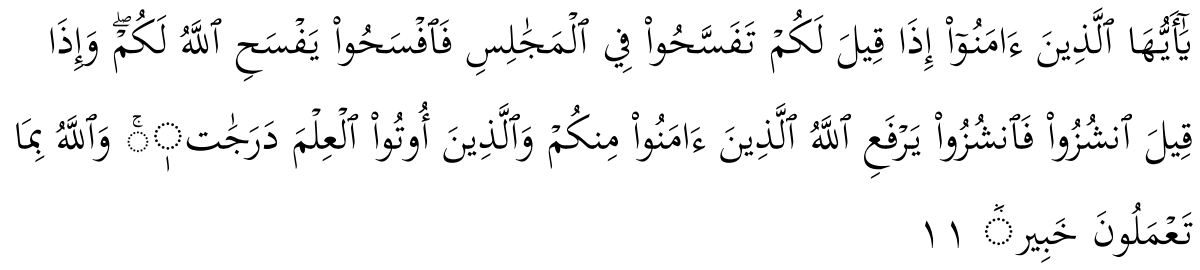

Dalam Tafsir Al Azhar dijelaskan: "Pertama jika seseorang disuruh melapangkan majlis, yang berarti melapangkan hati, bahkan jika dia disuruh berdiri sekalipun lalu memberikan tempatnya kepada orang yang patut didudukkan di muka, janganlah dia berkecil hati. Melainkan hendaklah dia berlapang dada. Karena orang yang berlapang dada itulah kelak yang akan diangkat Allah imannya dan ilmunya, sehingga derajatnya bertambah naik. Orang yang patuh dan sudi memberikan tempat kepada orang lain itulah yang akan bertambah ilmunya. Kedua memang ada orang yang diangkat Allah derajafrya lebih tinggi daripada orang kebanyakan, pertama karena imannya, kedua karena ilmunya. Setiap hari pun dapat kita melihat pada raut muka, pada wajah, pada sinar mata orang yang beriman dan berilmu. Ada saja tanda yang dapat dibaca oleh orang yang arif bijaksana bahwa si Fulan ini orang beriman, si fulan ini orang berilmu" (Hamka, Tafsir Al Azhar Jilid 9, 1965, hal. 7228-7229).

Dari ayat di atas, ada beberapa nilai terkandung: Allah SWT akan mengangkat derajat orang-orang yang beriman, yang taat dan patuh kepada-Nya, melaksanakan perintah-Nya, menjauhi laranganNya dan berusaha menciptakan suasana damai, aman dan tentram dalam masyarakat. Maka nilai-nilai ilahi, agama dan wahyu didudukan sebagai sumber konsultasi, sementara aspek-aspek 


\section{$e^{\text {I-Tarbawj Satria Kharimul Qolbi }}$}

kehidupan lainnya didudukan sebagai nilai-nilai insani yang mempunyai relasi horisontal lateral atau lateral sekuensal yang harus berhubungan vertikal linear dengan nilai-nilai Ilahi atau agama. Demikian pula, Allah SWT akan mengangkat derajat orang-orang yang berilmu yang menggunakan ilmunya untuk menegakkan kalimat Allah SWT. "Berarti Islam memang memotivasi kepada manusia untuk giat menuntut ilmu pengetahuan, karena dengan hal itu kedudukan kita akan tinggi dalam pandangan Allah SWT. Orang yang mendapatkan ilmu itu selanjutnya akan mencapai derajat yang tinggi dari Allah SWT" (Taufik, 2019).

Dalam aspek pendidikan Islam dapat kita cermati kedudukan orang yang berilmu sangatlah nampak. Para Imam Mazhab bahkan sampai saat ini masih terjaga nama dan karyanya. Khususnya di Indonesia para Walisongo penyebar agama Islam di Indonesia sampai dengan saat ini masih terawat ajarannya. Itu sema karena derajat orang yang berilmu sangatlah tinggi. Oleh sebab itu para tokoh-tokoh tersebut sabagai tauladan bagi kita untuk meningkatkan ilmu pengetahuan sebagai motivasi dan pedoman kita.

\section{c. Memudahkan Manusia Menemukan Hal Baru (Inovasi)}

Ilmu Pengetahuan akan memandu manusia dalam mencari jawaban-jawaban permasalahan di dunia yang belum terjawab. Kita perhatikan pada QS Ar Rahman (55): 33

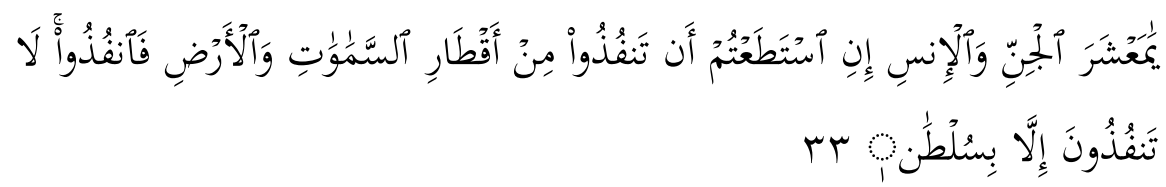

Tinjauan dari tafsir Al-Azhar dari ayat di atas adalah: "bahwa diantara Rahmat-Nya Allah itu kepada kita manusia dan jin ialah kebebasan yang diberikan kepada kita untuk melintasi alam ini dengan sepenuh tenaga yang ada pada kita, dengan segenap akal dan budi kita, karena mendalamnya pengetahuan. Namun, di akhir ayat 
Tuhan memberi ingat bahwa kekuatanmu itu tetap terbatas. Dala suku kata yang pertama, diberi kebebasan bagi manusia melintasi segala penjuru bumi, baik untuk mengetahui rahasia yang terpendam di muka bumi ini, ataupun hendak menuntut berbagai macam ilmu. Karena banyaklah rahasia dalam alam ini yang tersembunyi, yang sudah tabiat daripada manusia itu sendiri ingin tahu. Namun di suku kata yang kedua diberi ingat bahwa semuanya pekerjaan itu sangat bergantung kepada kekuasaan yang dalamnya disebut sulthan. Diberi ingat bahwasanya kalau kekuasaan tidak ada, pekertjaan akan terlantas di tengah" (Hamka, Tafsir Al-Azhar Jilid 8, 1965, hal. 7087).

Kemajuan dan perkembangan IPTEK (Ilmu pengetahuan dan Teknologi) yang dicapai manusia dari masa ke masa tenteu tidak lepas dari penyeledilikan manusia terhadap alam semesta beserta isinya. Maurice Bucaille berkata, "sungguh teknologi yang dalam hal ini merupakan atas Sulthan (kekuatan) sebagai kunci dari Tuhan untuk menggapai langit dan bumi mulai terungkap. Allah memberikan bimbingan-Nya dalam Al Qur'an sebagaimana cara memahami ayatayat yang berkaitan dengan alam semesta (Darmadi, 2017, hal. 63).

Ayat di atas memberi tahu manusia, bahwa dengan ilmu pengetahuan, manusia dapat melintasi alam semesta. Artinya, dapat menemukan hal-hal baru dalam ilmu pengetahuan untuk melakukan itu. Penemuan pengetahuan selalu berkelanjutan artinya akan ada penemuan-penemuan baru di berbagai bidang ilmu sesuai kebutuhan zaman. Sebagai umat Islam sudah sepatutnya kita berfikir inovatif mencari hal-hal baru dalam memberikan solusi terhadap masalahmasalah yang belum terselesaikan.

\section{Aplikasi Ilmu Pengetahuan dalam Perspektif Pendidikan Islam}

Ilmu pengetahuan ditempuh dengan berbagai proses yang sistematis sesuai dengan kemampuan dan kebutuhan. Implikasi dari kemampuan biasanya berkaitan dengan usia yang dimiliki manusia 


\section{$e^{\text {I-Tarbawj Satria Kharimul Qolbi }}$}

sehingga proses pemberian ilmu pengetahuan itu disesuaikan usia manusia. Dalam proses tersebut ada pembelajaran dengan berbagai metode, akan tetapi perlu kita sadari bahwa manusia diberikan karunia berupa akal pikiran untuk berfikir dalam menuntut ilmu pengetahuan. Beberapa proses yang akan kita bahas antara lain:

\section{a. Manusia Diberikan Akal Pikiran}

Ditinaju dari QS Al Baqarah ayat 31-32

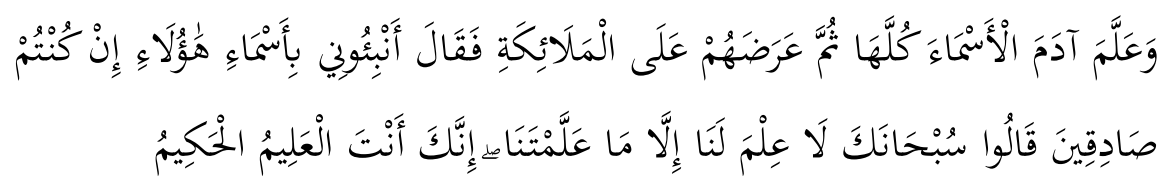

Artinya: "diberilah oleh Allah kepada Adam itu semua ilmu. Sesudah Adam diiadikan, kepadanya telah diajarkan oleh Tuhan nama-nama yang dapat dicapai oleh kekuatan manusia, baik dengan panca indera ataupun dengan akal semata-mata, semuanya diajarkan kepadanya. Kemudian malaikat Tuhan tanyakan adakah mereka tahu nama-nama itu? Jika benar pendapat mereka selama ini bahwa jika khalifah itu terjadi akan timbul bahaya kerusakan dan pertumpahan darah, sekarang cobalah jawab pertanyaan Tuhan: Dapatkah mereka menunjukkan nama-nama itu? Pada ayat (32) nampak penjawaban Malaikat yang mengakui kekurangan mereka. Tidak ada pada mereka pengetahuan, kecuali apa yang diaiarkan Tuhan juga. Mereka memohon ampun dan kurnia, menjunjung kesucian Allah bahwasanya pengetahuan mereka tidak lebih daripada apa yang diajarkan jua, lain tidak. Yang mengetahui akan semua hanya Allah. Yang bijaksana membagi-bagikan ilmu kepada barangsiapa yang Dia kehendaki, hanyalah Dia juga".

Menurut Rasyid Ridha, arti ta'lim adalah proses transmisi berbagi ilmu kepada jiwa individu tanpa adanya batasan dan ketentuan tertentu. Dalam pandangan al-Maraghi, kata at-ta'lim bermakna pengajaran yang dilaksanakan secara bertahap, 
sebagaimana tahapan Nabi Adam as. dalam mempelajari menyaksiakn dan menganalisa asma-asma yang diajarkan Allah kepadanya (Ahmad Izzanm, 2015, hal. 2).

Prinsip pendidikan salah satunya adalah meningkatkan potensi manusia. Artinya bahwa setiap manusia dapat berifikir dengan akal yang diberikan Allah SWT. Pendidikan sebagai tempat untuk mengarahkan menemukan potensi yang adapada manusia didasari ayat di atas di mana manusa memiliki kelebihan dibanding malaikat yaitu akal yang mampu menyerap ilmu pengetahuan.

\section{b. Pendidikan Sejak Dini}

Ilmu pengetahuan sejak dini dapat dilakukan dalam ruang lingkup keluarga. Pendidikan keluarga adalah pendidikan yang berlangsung di dalam keluarga terhadap anak-anak yang lahir di dalam keluarga atau anak-anak yang menjadi tanggung jawab anak tersebut. Hal ini terdapat penjelasannya pada QS At Tahrim:6.

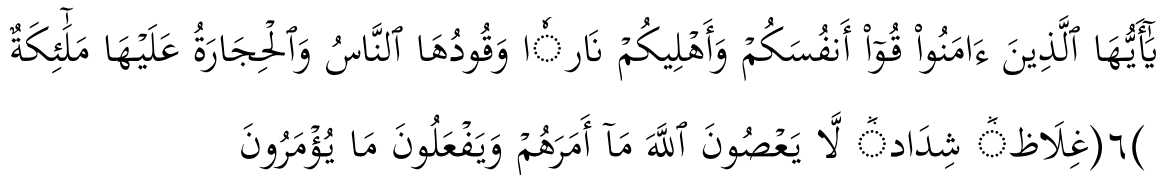

Menurut tafsir Al-Azhar, ayat di atas bermakna: “Di pangkal ayat ini jelas bahwa semata-mata mengakui beriman saja belumlah cukup. Iman mestilah dipelihara dan dipupuk, terutama sekali dengan dasar Iman hendaklah orang menjaga keselamatan diri dan seisi rumah tangga dari api neraka" (Hamka, Tafsir Al Azhar Jilid 8, 1965, hal. 7507).

Ayat ini menyiratkan perintah yang harus dipenuhi oleh kedua orang tua dari anak-anak mereka. Oleh karena itu, kedua orang tua harus dapat memainkan peran penting sebagai pendidikan pertama dan terdepan bagi anak-anak mereka, sebelum pendidikan anak-anak diserahkan kepada orang lain. Menurut Fuad Ihsan, tanggung jawab pendidikan oleh kedua orangtua meliputi memelihara dan 


\section{$e^{\text {I-Tarbawj Satria Kharimul Qolbi }}$}

membesarkan, melindungi dan menjamin kesehatan, mendidik dengan berbagai pengetahuan, dan membahagiakan anak-anak untuk dunia dan akhirat (Sulistyoko, 2018).

Pendidikan keluarga merupakan pendidikan dasar bagi anak. Dari ayat tersebut sangat jelas perintah orang tua dalam menjaga anaknya dari api neraka. Menjaga seorang anak dapat kita penuhi dengan pemberian ilmu pengetahuan pada anak. Ilmu yang paling penting adalah tentang Agama Islam yaitu tata cara menyembah Allah, tata cara bersosial menurut Islam dan tata cara menjaga harkat martabat seorang muslim. Pendidikan dasar inilah yang dapat membentuk karakter anak akan pentingnya ilmu Pengetahuan. Pada QS AL-Luqman:13

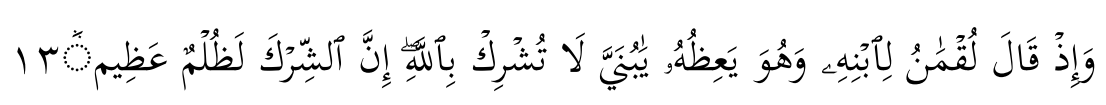

Tafsir Ibnu Katsir menjelaskan ayat di atas sebagai berikut: "Allah Ta'ala berfirman mengabarkan tentang wasiat Luqman kepada puteranya, yaitu Luqman bin 'Unaqa' bin Sadun. Sedangkan nama puteranya adalah Tsaran, menurut satu pendapat yang diceritakan oleh as-Suhaily. Allah telah menyebutkannya dengan sebaik-baik sebutan dan diberikannya dia hikmah. Dia memberikan wasiat kepada puteranya yang merupakan orang yang paling dikasihi dan dicintainya, dan ini hakikat dianugerahkannya ia dengan sesuatu yang paling utama. Untuk itu, pertama-tama dia memberikan wasiat untuk beribadah kepada Allah Yang Mahaesa yang tidak ada sekutu bagiNya" (Al-Sheikh, Tafsir Ibnu Katsir Jilid 6, 2003, pp. 400-401).

M. Yusud Efendi menjelaskan bahwa sebenarnya nasihat Luqman hanyalah nasihat ayah kepada anaknya sendiri. Tetapi Allah abadikan nasihat itu dalam Al Qur'an agar setiap umat dapat belajar dari apa yang dilakukan oleh luqman. Sebab peran ayah sangat penting dalam membentuk karakter anak sebagai belak kehidupannya (Darmadi D. H., 2018, hal. 29). 
QS AL Luqman ayat 13 sebagai penguat dalam pendidikan bahwa penanaman pendidikan akidah sangatlah penting bagi semuat umat. Bagi pendidikan keluarga sudah kewajiban bagi seorang ayah untuk mendidik anaknya untuk mengenalkan ke-Esaan Allah dengan berbagai metode agar anak mengerti betapa pentingnya kita sebagai manusia untuk tidak menyekutukan Allah.

\section{c. Proses Menuntut Ilmu Pengetahuan}

Menuntut ilmu pengetahuan sejatinya adalah proses dalam mencari ilmu penngetahuan. Apabila kita padukan dengan teori tentang ilmu pengetahuan di atas, maka menuntut ilmu adalah usaha dalam mencari suatu penemuan dengan berbagai metode yang sistematis dengan beberapa tahap tertentu agar mendapatkan hasil yang maksimal. Mencari ilmu pengetahuan berguna untuk sesuatu hal yang sebelumnya tidak diketahui. Beberapa proses cara dalam mencari ilmu pengetahuan dalam al-Qur'an adalah:

\section{1) Membaca dan Menulis}

Membaca merupakan perintah pertama dari Allah SWT terdapat pada QS Al-'Alaq: 1-2. Apabala kita tinjau dari proses pendidikan, membaca merupakan pembelajaran pertama bagi anak-anak. Membaca bertujuan agar anak-anak tidak buta huruf dan dapat mengenal suatu hal.

Setelah mampu membaca dilanjutkan dengan kegiatan menulis. Menulis berguna untuk merawat ilmu pengetahuan. Karya-karya berupa tulisan, buku-buku dan kitab merupakan bentuk tulisan. Dapat kita telaah pada QS Al-Qalam: 1:

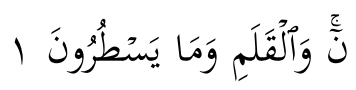

Menurut Tafsir Al-Azhar, ayat di atas bermakna: “tentang qalam, atau disebut juga pena, yang diambil menjadi sumpah utama oleh Tuhan di permulaan ayat satu, ada pula terdapat berbagai ragam 


\section{$e^{\text {I-Tarbawj Satria Kharimul Qolbi }}$}

tafsir. Ada yang mengatakan bahwa yarrg mula-mula sekali diciptakan oleh Tuhan dari makhluk-Nya ini tidak lain ialah qalam atau pena. Disebutkan pula bahwa panjang qalam itu ialah sepanjang di antara langit dan bumi dan dia tercipta dari nur, artinya cahaya. Dalam tafsiran itu dikatakan bahwa Allah memerintahkan kepada qalam daripada nur itu agar dia terus-menerus menulis, lalu dituliskannyalah apa yang terjadi dan apa yang ada ini, baik ajal atau amal perbuatan. Ada pula yang menafsirkan bahwa yang dimaksudkan dengan yang mula-mula diciptakan Tuhan ialah qalam, artinya ialah akal." (Hamka, Tafsir Al Ahar Jilid 8, 1965, hal. 7561).

Aktivitas membaca ini hendaknya diteruskan dengan aktivitas menulis (kitâbah) dengan menggukan pena ('allama bil-qalam) sebagai alatnya atau dengan menggunakan kecanggihan teknologi, seperti komputer. Pena dan alat tulis elektronik merupakan media yang berfungsi mengabadikan dan merekam pesan atau informasi yang kita peroleh sehingga pesan atau informasi tersebut dapat dikeluarkan atau dibaca ulang, baik oleh diri kita sendiri maupun orang lain. Akan tetapi sayangnya, aktivitas menulis kurang mendapatkan perhatian dari kebanyakan umat Islam. Mayoritas muslim cenderung lebih suka membaca dan belum terbiasa dengan kegiatan tulis menulis (Roqib, 2009, hal. 2).

Membaca dan menulis sampai saat ini tetap diterapkan oleh manusia. Apabila kita ambil makna dari membaca dan menulis ini dapat berupa meneliti, menelaah, mengkaji, diskusi dan membuat karya denga tujuan ditemukanlah ilmu-ilmu baru yang sebelumnya tidak ditemukan.

\section{2) Pendidikan Formal}

Ilmu Pengetahuan dari masa ke masa berisi keterkaitan antar ilmu satu dengan lainnya serta modifikasi-modifikasi terbarunya. Hal ini dipenaruhi perkembangan dan permasalahan dalam perbedaan masa. Setiap manusia memiliki potensi yang berbeda sehingga dalam 
ilmu pengetahuan terdapat orang-orang yang memiliki keahlian tertentu dalam bidang ilmu pengetahuan. Maka dari itu adanya kesadaran dalam menuntut ilmu tidak terbatasi oleh satu sudut pandang atau mempelajari satu bentuk ilmu dengan tidak mempelajari yang lainnya. Hal ini dipertegas oleh al-Qur'an QS AnNahl: 43:

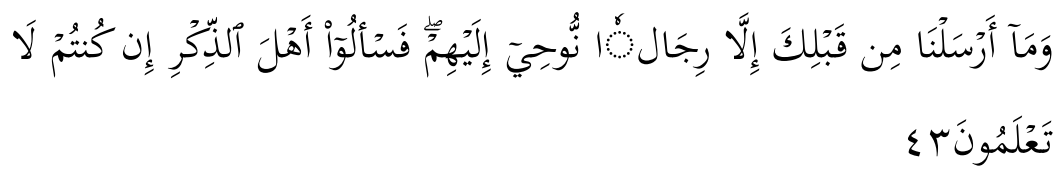

“Dengan ayat ini kita mendapat pengertian bahwasanya kita boleh menuntut ilmu kepada ahlinya, di mana saja dan siapa saja; sebab yang kita cari ialah kebenaran" (Hamka, Tafsir Al Azhar Jilid 5, 1965, hal. 3917).

Makna yang senada juga terdapat dalam QS Al-Anbiya':7. Dalam tafsir Al-Azhar, Ahlu adz-dzikri ialah ahli peringatan, atau orang yang lebih tahu, atau orang yang kuat ingatannya. Kebanyakan ahli tafsir mengatakan bahwa yang dimaksud ialah ahlul kitab yang terdahulu, yaitu orang Yahudi dan Nasrani. Menurut Sufyan bin Uyainah, maka dinamai "ahli peringatan" ialah karena mereka ingat akan khabar berita Nabi-nabi yang terdahulu dan orang Quraisy selama ini memang bertanya-tanya juga kepada ahlul kitab itu tentang hal-hal yang berkenaan dengan Nabi Muhammad s.a.w" (Hamka, Tafsir Al Azhar Jilid 5, 1965, hal. 4545).

Perhatian kita tertuju pada kalimat: "tanyakan ahlu al-dzikr, jika kamu tidak mengetahui". Zamaksyari dalam tafsirnya Al-Kasysyaf menafsirkan "ahlu al-dzikir" sebagai ahli kitab. Zamaksari menambahkan alasannya bahwa al-kitab itu sebagai mau'izhah dan tanbih li al-ghafilin (nasehat yang menyejukan dan menyenangkan orang yang dinasehati juga sebagai peringatan bagi orang-orang lalai). Al-Maraghi dalam tafsirnya menafsirkan QS. al_Anbiya/21:7 dengan menyebut bahwa ahlu al-dzikr itu yang beriman terhadap Taurat dan 


\section{$e^{\text {I-Tarbawj Satria Kharimul Qolbi }}$}

Injil. Dua kitab ini kata al-Maraghi akan memberitahukan "kamu" tentang kebenaran dan semakin jelas "bagimu" mana yang benar (alshawab) itu. Abi Hilal al-Askari dalam Mu'jam al Furuq al-Lughawiyah menyebut bahwa al-shawab itu konsisten baik dan benar. Al-Shawab dalam filsafat ilmu disebut teori koherensi di mana kebenarannya terletak pada konsistensi (Dalimunthe, 2018, hal. 126).

Dari makna ahlu al-dzikr bisa ditangkap substansinya dalam konteks pendidikan sebagai profesionalisme. Ahlu al-dzikri, dapat dipahami secara leterlek sebagai orang yang gemar berdzikir dengan ucapan kalimat-kalimat thayyibah yang terkenal, misalnya astaghfirullah, subhanallah, alhamdulillah, Allahu akbar, dan la ilah illa Allah". Jika rutin dibaca dan berulang-ulang dengan khusyu', kalimatkalimat dzikir itu bukan saja harmonis dengan lisan dan telinga yang mengucapkan dan mendengarnya, juga harmonis dengan akal dan kalbu. Maka profesionalisme dalam konteks ahlu al-dzikri adalah orang-orang yang spesialis dalam menguasai bidang ilmu. Mereka bukan saja menguasai ilmu juga menyukai ilmu tersebut, sehingga terjadi harmoni antara ilmu dengan kalbu dan perbuatan mereka (Dalimunthe, 2018, hal. 127).

Ilmu pengetahuan perlu diberikan wadah agar prosesnya dapat berjalan secara sistematis dan terstruktur. Maka dari itu, lembaga pendidikan atau sekolah adalah wadah yang tepat dalam hal ini. Sekolah merupakan tempat di mana setiap manusia belajar dalam menuntut ilmu. Ahlu al-dzikri dalam penjelasan di atas merupakan profesionalisme dalam pendidikan yang menguasai ilmu pengetahuan dalam bidangnnya. Dalam suatu lembaga pendidikan, terdapat guru dan dosen yang statusnya sebagai pengajar dalam bidangnya hal tersebut dapat dikatakan sebagai ahlu al-dzikri sehingga pendidikan formal sangat tepat dalam meletakan peran dari ahlu al dzikri. 


\section{Kesimpulan}

Dari beberapa teori diatas kita dapat cermati bahwa ilmu pengetahuan berawal dari proses dilakukan dengan metode dan menghasilkan suatu pengetahuan baru yang sistematis dan terstruktur yang akan dijadikan dasar pedoman bagi manusia. Pengertian ilmu pengetahuan diperkuat dengan QS An-Nahl:78 dimana pengetahuan itu hasil proses dari indera manusia mulai dari melihat mendengar dan berfikir. Proses-proses tersebut dimaknai bahwa yang namanya ilmu pengetahuan itu tidak instan terdapat tahap-tahap tertentu yang bersifat ilmiah serta dapat dipertanggungjawabkan

Hukum menuntut ilmu dalam Islam terdapat tiga bentuk. Pertama hukumnya wajib, yaitu wajib 'ain yang mempelajari ilmuilmu yang bersifat Tauhid dan wajib kifayah mempelajari Ilmu Tafsir, Hadits, Ilmu Kedokteran dll,. Kedua, hukum sunnah bagi ilmu-ilmu yang berkaitan dengan ibadah-ibadah sunnah. Ketiga hukum haram untuk mempelajarai ilmu yang dapat membahayakan orang lain. Hukum-hukum tersebut sebagai aturan untuk umat islam dalam anjuran menuntut ilmu. Agar manusia dapat memahami pentingnya menuntut ilmu.

Manfaat dan aplikasi dari ilmu pengetahuan bahwa ilmu pengetahuan bagian dari ibadah yang setara dengan jihad sehingga bernilai pahala, serta orang yang berilmu akan diangkat derajatnya sebagaimana pada QS At-Taubah: 122 dan QS Al-Mujadalah: 11. Untuk pengaplikasiannnya, pada dasarnya manusia memiliki akal untuk berfikir meneliti dan meninjau seperti dinyatakan QS. AlBaqarah: 31, ilmu pengetahuan dapat dilaksanakan sejak dini dengan pendidikan keluarga dengan sumber QS. At-Tahrim: 6 dan QS. Luqman: 13. Ilmu pengetahuan juga dilaksanakan dalam pendidikan formal yang dijelaskan pada QS An-Nahl: 43 dan Al Anbiya:7. 


\section{$e^{I-T a r b a w j}$ Satria Kharimul Qolbi}

\section{Daftar Pustaka}

Abidin, M. Zainal. (2010). Konsep Ilmu dalam Islam: Tinjauan terhadap Makna, Hakikat dan Sumber-sumber Ilmu dalam Islam. Ilmu Usshuludin Vol. 10, No. 1.

Al-Sheikh, D. A. (2003). Tafsir Ibnu Katsir Jilid 8. Bogor: Pustaka Imam Asyafi'i.

Dalimunthe, Sehat Sultoni. 2018. Filsafat Pendidikan Islam Sebuah Bangunan Ilmu Islamic Studies. Yogyakarta: Deepublish.

Darmadi, D. H. (2018). Mendidik Adalah Cinta: Menjelajah Pendidikan Rumah Anak di Rumah dan Sekolah. Surakarta: CV Oase Grup.

Darmadi, H. (2017). Integrasi Agama dan Ilmu Pengetahuan. Yogyakarta: Diandra Kreatif.

Djamil, A. H. (2015). Agar Menuntut Ilmu Jadi Lebih Mudah. Jakarta: Komputindo.

Hamka, P. D. (1965). Tafsir Al Azhar. Jakarta: Pustaka Nasional PTE LTD Singapura.

Ibnu Katsir, Ismail bin Umar. (2003). Tafsir Ibnu Katsir. Bogor: Pustaka Imam As-Syafi'i

Iryani, Eva. (2017). Al Qur'an dan Ilmu Pengetahuan. Jurnal Ilmiah Universitas Batanghari Jambi, Vol. 17, No. 3.

Ahmad. (2015). Tafsir Pendidikan: Konsep Pendidikan Berbasis Al Qur'an. Bandung: Humaniora.

Kosim, Muhammad. (2008). Ilmu Pengetahuan Dalam Islam: Perspektif Filosofis-Historis. Tadris Jurnal Pendidikan Islam Vol. 3., No. 2.

Makhmudah, Siti. (2018). Hakikat Ilmu Pengetahuan dalam Perspektif Modern dan Islam. Al-Murabbi, Vol. 4., No. 2.

Mardani. (2015). Hukum Islam; Pengantar Ilmu Hukum Islam di Indonesia. Yogyakarta: Pustaka Pelajar.

Mundiri. (2000). Logika. Jakarta: Raja Grafindo Persada.

Maragustam. (2015). Paradigma Revolusi Mental dalam Pembentukan Karakter Bangsa Berbasis Sinergitas Islam dan Filsafat Pendidikan. Jurnal Pendidikan Agama Islam Vol. 12, No. 2.

Rohidin. (2016). Pengantar Hukum Islam dari Semenanjung Arabia Menuju Indonesia. Yogyakarta: Lintang Rasi Aksara Books. 
Roqib, M. (2009). Ilmu Pendidikan Islam Pengembangan Pendidikan Integratif di Sekolah, Keluarga, dan Masyarakat. Yogyakarta: LKIS.

Shihab, M.Quraish. (1997). Ensiklopedia Al Qur'an. Jakarta: Yayasan Bimantara. . (1998). Menyikapi Tafsir Ilahi. Jakarta: Lentera Hati.

Santalia, Indo. (2013). Metode Ilmu menurut Perspektif AlQur'an. Tafsere Vol. 1., No. 1.

Sulistyoko, Arie. (2018). Tanggung Jawab Keluarga dalam Pendidikan Anak di Era Kosmopolitan: Tela'ah Tafsir Kontemporer atas Surat At Tahrim Ayat 6. Iqro: Journal of Islamic Education Vol.1, No.2.

Taufik. (2019). Integrasi Nilai Pendidikan Iman dan Ilmu Pengetahuan dalam Tafsir Al-Misbah: Kajian Surat Al-Mujadilah 58:11. Jurnal Pendidikan Islam, Vol 1, No.2.

Utsaimin, S. M. (2005). Syarah Adab dan Manfaat Menuntut Ilmu. Jakarta: Pustaka Imam Asy-Syafi'i.

Wahana, P. (2016). Filsafat Ilmu Pengetahuan. Yogyakarta: Pustaka Diamond.

Zainuddin, Ali. (2006). Hukum Islam, Pengantar Ilmu Hukum Islam di Indonesia. Jakarta: Sinar Grafika. 


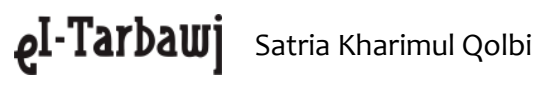

